\title{
Å forstå læringsprosessene i rollespill: Eksempel fra samfunnsfaget i larerutdanningen
}

\author{
Tove Leming \\ Institutt for lererutdanning og pedagogikk, Norges arktiske universitet (UiT), \\ Tromsø, Norge
}

\begin{abstract}
Sammendrag
Artikkelens tema er rollespill som arbeidsform i høyere utdanning, og hvordan man kan forstå læringsprosessene i denne arbeidsformen. Fokuset er på samfunnskunnskap i en norsk lærerutdanning, og det brukes konkret et eksempel fra undervisningstemaet familie, seksualitet og samliv. Målsetningen ved å bruke rollespill er å skape mer reflekterte og analytiske holdninger hos lærerstudenter i forhold til viktige verdivalg og situasjoner som møter dem i deres fremtidige lærerrolle, og på den måten bidra til at danningselementet i utdanningen styrkes. Ved hjelp av teorier om transformativ læring, samt tre ulike dimensjoner ved læring: innhold, drivkraft og samspill, analyseres erfaringer ved bruk av rollespill. Læringen foregår i en prosess med andre aktører, og i en kontekst hvor blant annet emosjoner kan ha betydning.
\end{abstract}

Nøkkelord: Profesjonsutdanning; studentaktive arbeidsmåter; samfunnskunnskap; transformativ lering

\begin{abstract}
This article discusses role play as a method of learning in higher education, and how we can be able to understand the learning process. The focus is on social science in a Norwegian teacher education, illustrated by an example from a course in this subject. The main objective by using role play is to create more reflective and analytical attitudes among teacher students in relation to important value choices and situations they will meet in their future teaching role. By using theories of transformational learning and theories of how the three learning dimensions: content, emotions and interaction, work together, the experiences by using role-play will be analyzed. The learning takes place in a process with others and in a context where emotions can play an important role.
\end{abstract}

Keywords: Professional education; student-centered teaching; social science; transformative learning

Received: August 2015; Accepted: February 2016; Published: April 2016

^Korrespondanse: Tove Leming, ILP, Norges arktiske universitet, UiT, Mellomveien 110, 9037, Tromsø. E-post: Tromsø tove.leming@uit.no 


\section{Tove Leming}

\section{Innledning}

Vi er $i$ gang med å utvikle rollespillet. Studentene er ivrige og skriver caser og rollekort. De snakker med lave, intense stemmer rundt bordene, slik at de andre gruppene ikke skal høre dem. Det er masse knising og dempet latter, de har det artig med de forskjellige karakterene de lager. Snart skal rollespillene gjennomføres, og en student kommer bort til meg med en håndskrevet lapp $i$ hånden. «Du, kan ikke du spille $i$ vårt rollespill?» sier hun, og gir meg lappen som er rollekortet. Feg rister på hodet, men kikker på rollekortet, og må bare smile. Der står det: "Din rolle: du er en kvinnelig laerer $i$ samfunnsfag som er overivrig etter à spille rollespill».

Slik kan man av og til bli konfrontert med seg selv og sine særinteresser, og det er slike små episoder som gjør det spennende og utfordrende å arbeide med læringsprosesser innenfor høyere utdanning. Som også gjør at jeg blir nysgjerrig på hvordan læringsprosessene foregår, nysgjerrig på hva studentene lærer og ikke minst hvordan de lærer. Og som gjør at det blir viktig for meg å legge best mulig til rette for at de skal få et godt utbytte av undervisningen og vokse personlig på veien mot sitt nye yrke. Spesielt det siste oppfatter jeg som en viktig del av den danningsprosessen de gjennomgår på veien mot læreryrket. At jeg kanskje oppfattes som «overivrig etter å spille rollespill», bekymrer meg ikke. I høyere utdanning er det å fremme studentaktive arbeidsmåter et av målene for å bedre kvaliteten i utdanningene. Det er derfor også viktig å utvikle FoU-basert kunnskap om slike arbeidsmåter.

I denne artikkelen vil jeg fokusere på bruk av rollespill i en profesjonsutdanning. Jeg vil ta utgangspunkt i den norske lærerutdanningens samfunnskunnskap og bruke fagets innhold og tematikk som ramme. Gjennom et eksempel vil jeg presentere hvordan jeg har brukt rollespill aktivt i egen undervisning, og hvordan jeg har systematisert disse erfaringene slik at de utgjør den empiriske basisen for mitt forsknings- og utviklingsarbeid. Mitt spørsmål i denne artikkelen er hvordan vi ved hjelp av teorier og begreper kan forstå de mange prosesser som foregår i rollespill. Gjennom bruk av teorier om transformativ lering (Mezirow, 2000), samt Knud Illeris teorier om de tre læringsdimensjonene: innhold, drivkraft og samspill (2012), analyserer og diskuterer jeg dette spørsmålet med bakgrunn i egen praksis. Det finnes flere faglige perspektiver og forståelsesmåter knyttet til spillprosesser: til både endringsprosessene som foregår i den enkelte deltaker, og endringsprosessene i en større sosial enhet eller i et samfunn (Schechner, 2003; Boal, 1985). Mitt fokus i denne artikkelen er primært avgrenset til læringsteoriene til Mezirow og Illeris.

\section{Perspektiver og begreper for å forstå laringsprosessene i rollespill}

Den amerikanske sosiologen Jack Mezirow lanserte rundt tusenårsskiftet sitt begrep transformativ laring (Mezirow, 2000). Hans arbeid med læring for voksne, bidro til at han søkte andre måter å forstå læringsprosesser på enn de som anvendes i læring med barn. Utgangspunktet for teorien om transformativ læring, er at mennesker søker etter å skape mening gjennom de erfaringer man har. I en læringsprosess vil derfor både erfaring, mening og refleksjon være viktige komponenter. Våre referanserammer 
er strukturer av kultur og språk, de former og begrenser vår oppfattelse, vårt tankemønster og våre emosjoner. Den ene dimensjonen er habit of mind. Den omfatter meningsperspektiver som er de sentrale og overordnede rammene for vår dannelse av mening. Disse utvikles igjennom vår oppvekst, og styrer (både bevisst og ubevisst) vår oppfattelse, forståelse og innstilling generelt.

Den andre dimensjonen i referanserammene er meningsskjemaer, point of view. Disse er utgangspunkt for våre holdninger, ideer, verdier, atferd, samt de mentale vaner som følger av meningsperspektivene våre (Illeris, 2012; Mezirow, 2006). Mezirow bruker som eksempel etnosentrisme som en del av et meningsperspektiv i form av en tro på at andre som ikke tilhører ens egen gruppe er inntrengere, upålitelige og ikke uten videre kan aksepteres, men som meningsskjema artikuleres dette ved at man kan ha negative følelser og holdninger til bestemte grupper eller individer som er annerledes enn vår egen gruppe. Å ha en positiv erfaring med en av disse gruppene, kan bety at vi kanskje endrer vårt point of view, meningsskjema, men ikke nødvendigvis at vi endrer vår habit of mind, vårt meningsperspektiv (Mezirow, 2006). Transformativ læring omhandler den transformasjonen som skjer $\mathrm{i}$ individet når man endrer sine meningsperspektiver, gjennom at man vurderer, blir bevisst og reflekterer kritisk over egne meningsperspektiver. Man kan også si at meningsperspektiver og meningsskjema er deler som inngår i det vi kan definere som kultur, forstått som den deskriptive, samfunnsvitenskapelige definisjonen på kultur (Klausen,1992; Eriksen, 2010). Kultur skapes og vedlikeholdes $\mathrm{i}$ et samspill mellom læring og sosialiseringsprosesser, og meningsperspektiver og meningsskjema dannes i koblingen mellom enkeltindivider og kulturelle føringer.

At læring kan ha en slik endringskraft, både individuelt og samfunnsmessig, kjenner vi blant annet igjen fra Paulo Freires frigjørende pedagogikk (Freire, 1970). Freire så på utdanning som en måte for å utvikle en mer omfattende transformasjonsprosess, og som et verktøy for å endre grunnleggende maktstrukturer i samfunnet. Kvinnebevegelsen blir også brukt som eksempel på en transformativ læringsprosess. Kritiske spørsmål og refleksjoner rundt rolleforventninger til kvinner over tid har ført til fundamentale endringer av kvinners vilkår primært i den vestlige delen av verden (Mezirow, 2006).

Illeris (2012) videreutvikler begrepet transformativ læring ved å tydeliggiøre det emosjonelle aspektet ved læring. Dette gjør han gjennom presisering av at læring kan studeres igjennom tre dimensjoner: innhold, drivkraft og samspill. Læringens innhold kan forstås som det kognitive aspekt ved læring, altså det konkrete som skal læres. Læringens samspill dreier seg om det relasjonelle og sosiale aspekt ved læring, altså den sosiale og samfunnsmessige kontekst læring foregår i. Læringens drivkraft handler om motivasjon, følelser og vilje til læring. Illeris argumenterer for at Mezirows teorier om transformativ læring mangler et tydeligere fokus på den emosjonelle dimensjonen ved læring. Læringens drivkraft dreier seg om den mentale energien som legges i læringsprosesser, gjennom motivasjon, følelser og vilje (Illeris, 2012; Illeris, 2013). Denne presiseringen av emosjonenes betydning i læringsprosesser er viktig, ikke minst fordi det i den generelle diskursen rundt forskning og læring legges lite vekt på emosjonenes betydning (Tiller, Leming \& Jakhelln 2009). De emosjonelle prosessene 


\section{Tove Leming}

har mange spekter: Følelser og normer rundt følelser skapes gjennom sosialt samspill og sosial/kulturell påvirkning (Starrin, 2009). Dette fokuset vektlegger det samfunnsmessige og relasjonelle aspektet ved emosjoner, mer enn kun det rent individuelle og psykologiske aspektet.

Læring foregår også i en sosial kontekst og i et samspill med andre. Hvordan individer tilegner seg kunnskap, henger blant annet sammen med hvilke relasjoner individet har med andre, og hvordan det sosiale fellesskapet rundt er konstruert. Situert laring (Lave \& Wenger, 1991) er en slik «relasjonell og situert forståelse av læring» (Filstad, 2010), hvor individet utvikler kunnskap i et praksisfellesskap, i en bestemt sammensetning av aktører (Wenger, 1998). Læringen foregår også i en samfunnsmessig kontekst som legger noen premisser for læring, og til sammen utgjør disse elementene læringens samspillsdimensjon.

\section{Fokus på egen praksis: datagrunnlag og metodisk tilnarming}

Jeg har flere års erfaring med rollespill gjennom å undervise i samfunnsfag ved lærerutdanningen. Disse rollespillene har jeg enten arbeidet med alene, eller sammen med kollegaer. Når jeg bruker rollespill jevnlig, er det fordi jeg tror, og har erfart, at denne arbeidsformen er et godt supplement til andre arbeidsformer i høyere utdanning. Som tidligere nevnt ble jeg nysgjerrig på selve læringsprosessen i rollespill, og begynte etter hvert å be studentene om å skrive refleksjonsnotater i tilknytning til rollespillene. I denne artikkelen har jeg valgt å ta utgangspunkt i konkrete rollespill jeg har gjennomført blant lærerstudenter på integrert master i lærerutdanning ved egen institusjon. Studentene var da i sitt første eller andre studieår. Disse studentene har valgt samfunnsfag som et av sine fag i utdanningen. Samfunnskunnskap utgjør omtrent en tredjedel av faget, ved siden av geografi og historie.

Mitt skriftlige empiriske materiale er studentenes refleksjonslogger både før og etter rollespillet. I tillegg til studentenes refleksjonsnotater har jeg systematisk ført forskerlogg, hvor jeg har skrevet ned mine observasjoner og refleksjoner igjennom hele prosessen. Informasjonen jeg fikk inn, både av skriftlig og muntlig karakter, har jeg tolket i lys av de teoretiske perspektivene og begrepene jeg lanserte tidligere. Utvalget besto av refleksjonsnotater fra til sammen 16 tekster, og egen forskerlogg gjort før, under og etter begge rollespillene. I forskerloggen skrev jeg ned forventninger jeg hadde til rollespillet, hvordan jeg planla å gjennomføre det, og egne tanker og emosjoner. Jeg noterte hva som skjedde underveis i rollespillene, og oppsummerte hva som skjedde i diskusjonene etter rollespillene. Refleksjonsnotatene fra studentene varierte i omfang; fra to-tre setninger til større tekster. De var også ganske ulike i refleksjonsnivå. Med utgangspunkt i disse dataene dannet jeg meg et helhetsinntrykk av materialet. Jeg valgte å bruke teorien om transformativ læring som bakgrunn for å forstå prosessen i den muntlige diskusjonen, og Illeris' tre dimensjoner om læring som grunnlaget for kategoriene jeg plasserte tekstene fra studentene i.

Alle studentene har blitt informert om at rollespillene jeg har gjennomført er en del av et eget forsknings- og utviklingsarbeid, og at jeg bruker dataene jeg får inn i en anonymisert form. Det er allikevel viktig å reflektere over den etiske dimensjonen 
i prosjektet. Det er to sider ved denne; for det første kan selve rollespillet igangsette emosjoner hos både studentene og hos meg som lærer. Her har jeg et etisk ansvar som leder av en prosess som fremkaller emosjoner, og som i neste omgang kan berøre studentene på måter jeg ikke nødvendigvis kan overskue. Dette er kanskje spesielt viktig i dette rollespillet jeg brukte; det omhandler temaet familie, seksualitet og samliv.

Å lede læringsprosesser, og samtidig skulle ha et analytisk, forskende blikk på prosessen, stiller krav til refleksjon over egen rolle gjennom fokus på både refleksivitet (Hammersley \& Atkinson, 1996), og på forholdet mellom nærhet og distanse (Repstad, 2009). Som deltagende observatør av rollespillene, men også innimellom inne i en intervenerende deltagerrolle (Fangen, 2010), måtte jeg finne en balanse i forhold til når og hvor min tilstedeværelse skulle berøre prosessen. Det var for eksempel viktig for meg å få frem studentenes egne refleksjoner etter rollespillene, refleksjoner som ikke ble styrt inn i de tilbakemeldinger jeg som lærer og forsker ønsket. Derfor valgte jeg tilbakemeldinger skriftlig og individuelt. Jeg var på jakt etter den enkelte students umiddelbare og upåvirkede refleksjon om det å være deltager i et rollespill, og jeg ønsket muntlige refleksjoner gjennom felles samtaler om rollespillene etterpå.

Som forsker har jeg et spesielt ansvar i lys av det asymmetriske maktforholdet mellom lærer og student. Jeg bruker deres emosjoner som mitt empiriske materiale, deres utsagn og refleksjoner blir analysert, plukket fra hverandre og satt inn i en annen kontekst som studentene ikke nødvendigvis kjenner. Studentenes emosjoner kan fort bli data som de produserer, leverer og mister kontrollen over (Ghaye, 2007).

\section{Rollespill i profesjonsutdanning}

Rollespill kan være alt fra samtaler av terapeutisk karakter, til kompliserte nettbaserte rollespill med spillere på hver sin side av kloden. Målene med rollespill varierer også, fra å konkretisere vanskelig fagstoff, utforske holdninger og handlingsalternativer, til å trene profesjonsutøvere på situasjoner som vil oppstå i arbeidslivet. Mitt fokus i denne artikkelen er rettet mot høyere utdanning, og innenfor dette området brukes rollespill og dramametoder innenfor mange typer utdanninger og faglige områder, eksempelvis innenfor naturfag og helsefaglige utdanninger som sykepleier- og medisinutdanninger (Ekebergh, Lepp \& Dahlberg 2004). Innenfor lærerutdanning generelt kan man bruke studenters erfaringer fra praksis som utgangspunkt for ulike former for rollespill, for eksempel som basis for å diskutere og å reflektere med medstudenter og lærere. Temaer som klasseledelse, elevsamtaler og kommunikasjon med foreldre med ulik kulturell bakgrunn, kan spilles ut og bearbeides ved hjelp av rollespill og forumteater (Eriksen, Larsen \& Leming, 2014).

Bruken av rollespill i lærerutdanningens samfunnskunnskap kan ha flere formål. Som lærerutdanner ønsker man å styrke studentenes læring og kunnskap om faglige tema innenfor læreplanens ramme, men bruk av rollespill kan også ha en eksemplarisk verdi. Studentene får på denne måten kjennskap til et didaktisk verktøy de kan anvende når de går inn i en ny rolle som ferdigutdannet lærer. 


\section{Tove Leming}

Innenfor det samfunnsfagdidaktiske fagmiljøet nasjonalt, brukes ofte rollespill som eksempel på hvordan man kan arbeide med ulike tema i undervisningen i grunnskolen, fra internasjonale konflikter til undervisning om seksualitet og samliv (Koritzinsky, 2014; Børhaug, Christophersen \& Aarre, 2014). Rollespill kan eksempelvis kobles til Storyline som undervisningsmetode, en tverrfaglig undervisningsform hvor elevene blant annet skaper karakterer som de handler ut fra i en gitt kontekst. Målet er å skape læring gjennom konstruktivistiske læringsprosesser hvor utforskende elever er mer motivert for faglig kunnskap (Eik, 1999).

I det norske Læreplanverket for Kunnskapsløftet i grunnskolen, fokuseres det blant annet på at elevene skal kunne håndtere ulike meninger og perspektiver. Dette er overordnede mål i faget Samfunnsfag gjennom hele utdanningsforløpet i grunnskolen og videregående opplæring (Utdanningsdirektoratet, 2013). Det tematiseres også at møter mellom ulike mennesker kan være både givende og konfliktfylte. Evnen til empati nevnes i et av kompetansemålene, og rollespill kan være et verktøy for å styrke elevenes empatiske evner.

Innenfor lærerutdanningens samfunnskunnskap er tema som forholdet mellom individ og samfunn, flerkulturell forståelse, demokrati, menneskerettigheter, likestilling og så videre, eksempler hvor rollespill er en mulig arbeidsform. Gjennom rollespill kan man bevisstgiøres egne holdninger og antagelser om sammenhenger, og hvordan disse holdningene og antagelsene er en forforståelse man har i seg som et produkt av et samfunn med gitte kulturelle og sosiale normer. Det er viktig å gi studentene muligheter til å prøve å inneha et annet perspektiv, og å ta et steg til siden for å forstå et fenomen fra en annen synsvinkel. Mine antagelser er at man gjennom å bruke rollespill kan giøre nettopp dette. Å bruke rollespill kan gi andre og komplementære innganger til en læringsprosess, ikke bare gjennom rent kognitive prosesser, men også gjennom prosesser hvor de emosjonelle sidene aktiveres. Et rollespill gir dermed muligheter for å kjenne på kroppen hva det betyr å være i ulike roller, en kroppssliggjøring av kunnskap som kan gi en annen dybde i læringen. Rollespill kan gi styrke til et mer analytisk ståsted i forhold til egen praksis og yrkesutøvelse. I rollen som samfunnsfagslærer, og med viktige verdispørsmål på timeplanen, er det viktig å inneha et analytisk perspektiv på sin rolle som verdiformidler.

Rollespill som arbeidsform kan for noen studenter gi dårlige assosiasjoner, noen har ikke spesielt gode erfaringer med denne arbeidsmåten. Tema som tas opp igjennom rollespill, kan være betente og utløse negative emosjoner som giør læringsperspektivet meningsløst. Karakterene som blir synlige i rollespill, kan virke støtende og fordummende, og hele læringsprosessen kan få en uønsket retning. Mer kunnskap om læringsprosessene i bruk av rollespill blir derfor kanskje enda mer viktig?

Som jeg nevnte tidligere, er dannelsesaspektet i profesjonsutdanning sentralt. Studentene er i en prosess hvor en sterk og klar faglig identitet også skal skapes og utvikles. Rollespill er en deltakeraktiv læringsform, og det er viktig at studentene også får kompetanse i det å utforske slik erfarings- og opplevelsesbasert kunnskap. En slik kompetanse vil være en sentral del av en dannelsesprosess. 
Det vanskelige temaet familie, seksualitet og samliv

Jeg har variert mellom ulike former for rollespill, gjerne ulike i struktur og innhold, avhengig av hvilken tilnærming jeg ønsker. Rollespillene kan ha ulik grad av kontroll og forberedelser i gjennomføringen, og de kan belyse forskjellige tematiske områder.

I dette konkrete opplegget fikk studentene i oppgave å lage rollespillet selv, det vil si utvikle karakterer, skissere opp et dilemma eller en konflikt, og sette opp selve strukturen. På denne måten skulle de selv utforske rollespillet som didaktisk verktøy. Studentene hadde spilt andre typer rollespill tidligere og kjente til de grunnleggende trekkene med rollespill: at situasjonen måtte utvikles slik at temaet kom tydelig frem, at de enkelte rollefigurer måtte gjennomtenkes og skapes, og at dramaturgien rundt rollespillet kunne fungere bra.

De skulle deretter be en av de andre studentgruppene om å spille selve rollespillet på basis av de instrukser de laget i gruppa. Jeg ba dem fokusere på hvordan man som lærer kunne kommunisere rundt et slikt sårbart tema, og ba dem ta utgangspunkt i to oppgitte kompetansemål på 10. trinn i LK06 som begge omhandlet seksualitet og samliv. Det ene lød slik: «gje døme på korleis oppfatningar om forholdet mellom kjerleik og seksualitet kan variere i og mellom kulturar», og det andre var formulert som: «analysere kjønnsroller $i$ skildringar av seksualitet og forklare skilnaden på ønskt seksuell kontakt og seksuelle overgrep» (Utdanningsdirektoratet 2013).

Studentene ble delt inn i grupper som fikk fordelt tre ulike situasjoner de skulle bygge rollespillet rundt: et foreldremøte hvor det ble informert om lærerens planer rundt temaet, et trinnlærermøte på ungdomsskolen hvor det skulle planlegges et prosjekt innenfor temaet, samt en læringssituasjon i en 9. klasse hvor lærerne gjennomførte et undervisningsopplegg de hadde laget knyttet til temaet seksualitet og samliv. Innenfor disse rammene fikk de i oppgave å utvikle karakterene individuelt og gruppevis, samt organisere gjennomføringen av rollespillene. Arbeidet med rollespillene gikk over to dager, totalt 6 timer. Rollespillene ble spilt ut sekvensielt mot slutten andre dag, og alle studentene var samlet. Hvert rollespill ble avsluttet med at hver student fikk si noe om det å være i sin rolle, og deretter fulgte en kort diskusjon om selve rollespillet hvor alle studentene deltok. Etter alle rollespillene avsluttet vi med diskusjoner, individuelle skriftlige refleksjoner og til slutt felles muntlige refleksjoner, ledet av meg.

Alle rollespillene skapte engasjement i fremføringen, men rollespillet om foreldremøtet skapte spesielt mange diskusjoner og emosjoner $\mathrm{i}$ form av følelsesmessige utbrudd og frustrasjoner når man ikke fikk samarbeidet til å fungere. Karakterene de hadde forberedt til foreldremøtet, var blant annet en far med annen kulturell bakgrunn hvor seksualitet var et tabuområde, homofilt par med barn, feministisk mor, overbeskyttende mor osv. De ulike karakterene hadde beskrevne personlighetstrekk, samt instruksjoner om hvilket ståsted de skulle ha i diskusjonen som fulgte etter at læreren hadde presentert sine planer.

I rollespillet hvor situasjonen var et trinnlærermøte på ungdomsskolen, ble også mange ulike perspektiver på temaet lansert: alt fra den strengt religiøse og pietistiske læreren som ønsket minst mulig fokus på seksualitet som tema i skolen, til den åpne og 


\section{Tove Leming}

direkte helsesøsteren som syntes dette var et helt naturlig tema å snakke om. Å planlegge et felles prosjekt med såpass ulike holdninger til temaet, viste seg å være vanskelig og krevende. Deltagere i klasserommet i 9. klasse var elever med ulike instruksjoner til hvordan de skulle være i rollene: fra sjenerte og ordknappe tenåringer, til utagerende elever som hadde et sterkt behov for å sees. De ulike rollekarakterene gjenspeilte også et mangfold i forhold til religiøs og kulturell bakgrunn. Felles for alle rollespillene var at studentene selv hadde utviklet de ulike karakterene, og i refleksjonene etter hvert rollespill diskuterte vi blant annet hvordan karakterene ble skapt, og hva slags kunnskap og holdninger som ligger bak når en utvikler en slik karakter. Det didaktiske valget jeg gjorde ved å la studentene selv i så stor grad konstruere rollespillene og skape karakterer, kan først og fremst begrunnes i et ønske om å styrke studentaktive arbeidsmåter ytterligere. Men det er like viktig at det å arbeide med rollespill er eksemplarisk læring; studentene lærer ikke bare å delta, men også å utvikle og å lede rollespill. Denne erfaringen kan de bruke i egen fremtidig praksis som lærer.

I denne muntlige diskusjonen observerte jeg at flere av studentene var opptatt av at det i rollespillet ble utformet karakterer med litt for ekstreme trekk, særlig i forhold til religiøsitet og kultur. Det ble argumentert med at virkeligheten var langt mer mangfoldig enn rollespillet viste, og i akkurat denne dialogen begynner studentene å stille spørsmål om sine overordnede referanserammer, sine habits of mind. Hva slags oppfatning har jeg om for eksempel mennesker med religiøse overbevisninger, enten det er knyttet til kristendommen eller islam? Hvor kommer denne oppfatningen fra? Dette ble utgangspunkt for en større diskusjon som handlet om hvordan vi som etnisk norske ofte bruker grove kategorier når vi møter mennesker med andre kulturelle og religiøse verdier. Diskusjonen omhandlet også hvordan vi ser på oss selv som et resultat av gitte verdisystem. Prosessen jeg observerte i denne diskusjonen, kan knyttes til teorier om transformativ læring. Mezirow (2006) bruker, som nevnt tidligere, begrepet etnosentrisme som et eksempel på meningsperspektiver, habits of mind, altså oppfattelse, forståelse og innstilling til andre grupper. Det er viktig å presisere at studentenes meningsperspektiver nødvendigvis ikke må oppfattes som feil, eller som noe som skal endres $\mathrm{i}$ «riktig» retning. Det som er viktig i denne sammenhengen, er å stimulere studentene til å kunne ha en analytisk distanse til seg selv og egen praksis som lærer ved at deres meningsperspektiver utfordres. I dette ligger også et endringspotensiale. Å bli bevisst og reflektere kritisk over sine egne meningsperspektiver er en del av en transformativ læringsprosess, som også kan innebære endringer i studentenes forståelse av seg selv og en endring i studentenes point of view, som for eksempel kan være holdninger til grupper med annen religiøs og kulturell bakgrunn.

Jeg introduserte tidligere de tre dimensjonene ved læring: innhold, drivkraft og samspill (Illeris, 2012). Læringens innholdsdimensjon dreier seg om blant annet kunnskap, ferdigheter og kompetanse, med bakgrunn i forståelse og innsikt i temaet. I våre rollespill handlet innholdsdimensjonen om håndtering av temaene kjønnsroller, seksualitet og kjærlighet og kulturelle variasjoner innenfor disse begrepene. Tematisk er ikke dette noe enkelt tema å formidle, verken for meg som lærer eller for studentene 
som fremtidige lærere. En av studentene skriver, før rollespillet: «feg opplever seksualitet som et sårt eller vanskelig tema. Som elev tor man ikke helt à si hva man tenker, og som larer kan jeg tenke meg at det er et steg utenfor komfortsonen i forhold til hvordan man vil at elevene skal oppfatte en».

Noen studenter skrev at de ikke hadde fått så mye ny faglig kunnskap om temaet Noen hadde hatt en del om dette temaet tidligere, for eksempel på videregående, så forutsetningene var nok litt ulike i utgangspunktet. En student skriver for eksempel: «Har kanskje ikke lert så veldig mye, men blitt bevisst på at det finnes ulike holdninger knyttet til temaet», en annen sier: «Det faglige innholdet forsvant litt...det faglige innholdet kan vi kanskje relatere til hva vi skal mote som larere og hvordan vi skal håndtere dette». Disse uttalelsene viser at det kognitive læringselementet er knyttet til ferdigheter i å takle et slikt tema, mens faglige, mer faktabaserte kunnskaper, følte de at de fikk mindre av.

Illeris' andre dimensjon kaller han læringens drivkraft. Den består av tre elementer: motivasjon, følelser og vilje til læring, det jeg definerer her som emosjoner. I rollespill er det emosjonelle perspektivet vanligvis fremtredende. Dette er en arbeidsform som legger til rette for følelsesmessig engasjement og studentenes refleksjoner rundt dette. I selve rollespillet går man inn i en rolle, og dette skaper følelsesmessig engasjement igjennom innlevelse og identifikasjonsprosesser (Eriksen \& Leming, 2006, 2007). Noen studenter har større evne til innlevelse enn andre, men alle berøres på en eller annen måte.

I refleksjonsnotatene kommer det emosjonelle engasjementet fram igjennom to ulike former for uttalelser: «Man ble lett engasjert og kanskje litt lettere provosert dersom det var noen som var uenige eller kom med andre forslag enn mitt》, og "gjennom rollespill bringer man ofte mer latter inn i timene, dette kan sees på som en mulighet for at elevene husker det faglige fordi det var gøy». Det første utsagnet er et eksempel på hvordan studentene føler at de ble følelsesmessig berørt av rollespillet, det andre er en refleksion over det emosjonelle aspektet ved bruk av rollespill som metode i framtidig yrkesutøvelse. Bruk av rollespill kan styrke motivasjonen for å lære, eller som en av studentene formulerer det: «feg leerte at man kan tilegne seg kunnskap på en annen og morsommere måte. En kan si at man larer uten å føle at man larer». Læring generelt oppfattes tydeligvis som noe vanskelig, mens bruk av rollespill representerer for denne studenten en motvekt til tunge læringsprosesser. At læringsprosesser er vanskelige, kan neppe generaliseres, men det er interessant hvordan så og si alle studentene gir positiv tilbakemelding på rollespill som metode, enten som et avbrekk fra vanlig undervisning, eller fordi de liker denne måten å arbeide på.

Som jeg nevnte over, leser jeg av refleksjonsnotatene at mange av studentene mener at de har lært mest om metode, og mindre om selve temaet familie og samliv. Men det å være inne i en annen rolle og kjenne etter hvordan det er, mener studentene er en styrke for dem som lærere: «Man får også brukt folelsene, noe som kan vare med på å styrke handlingsrepertoaret når man kommer $i$ slike situasjoner». "Følelsene» som det refereres til her, kan tolkes på to måter. På den ene siden kan man betrakte det som et individualistisk og psykologisk fenomen. Men det kan også analyseres som det 


\section{Tove Leming}

samfunnsmessige og relasjonelle perspektivet på emosjoner; følelser er noe som oppstår i samspill med andre.

Dermed er vi inne på Illeris’ tredje dimensjon av læring, samspill. Samspill omhandler læringsprosessens relasjonelle aspekt, den sosiale sammenheng som læring inngår i. Selv om Illeris også legger til en samfunnsmessig kontekst i dette begrepet, velger jeg i dette tilfellet å definere dette som den sosiale og materielle omverdenen læringen foregår i. Læringen foregår i denne gruppen, som består av studentene og meg. Vi utgjør et praksisfellesskap, og læringen foregår som et resultat av en dialog mellom deltagerne i gruppen, og ikke som et resultat av at jeg står ved tavla og framfører en monolog. En student beskriver på en konkret måte gevinsten av denne måten å arbeide på: «Dette gjør at jeg får andre synspunkter enn bare det jeg selv tenkte på, noe som gjør at jeg fär bredere innsikt $i$ temaet».

Samspilldimensjonen er sentral i rollespill, både i forberedelsene, gjennomføring av spillet og i refleksjonene etterpå. Rollespill kan bidra til at tause og inaktive studenter løser mer opp. Jeg har erfart at det at studentene tar på seg en annen rolle, også gir dem en litt annen mulighet til å delta mer aktivt i læringsprosesser enn de vanligvis gjør. En transformativ læringsprosess betyr at man stiller spørsmål ved egne referanserammer. Som lærer i grunnskolen er det viktig å være i stand til nettopp dette gjennom å inneha en analytisk rolle i forhold til det lærestoffet man formidler og de holdninger elever og foreldre representerer. Dette ble nevnt av flere studenter, blant annet en som formulerte seg slik: «En larer må sette seg inn $i$ ulike situasjoner, og kunne løse konflikter. Man må ta hensyn til religion, kjønn, elevenes meninger og deres og andres livssyn».

\section{Rollespillets muligheter i kobling med fag}

Det ligger et potensiale i det å bygge videre rundt refleksjonene etter et gjennomført rollespill, og å skape en dialog som ivaretar den reisen studentene har vært på gjennom det å inneha forskjellige roller. Dialogen kan organiseres på en mer systematisk og strukturert måte, med utgangspunkt i de ulike historiene studentene har fătt tilgang til gjennom rollespillet de har deltatt i. Det er disse emosjonelle og kognitive konkrete erfaringene de har som kan åpne opp for videre utvikling og nye perspektiver.

Målet med et rollespill er ikke først og fremst å formidle faktakunnskap, men at studentene skal oppnå at egne referanserammer utfordres. De skal klare å se og forstå fenomener ved hjelp av ulike perspektiver. Det vil være et supplement til faglig formidling, en komplementær måte å lære på. Å klare å gjøre en god kobling mellom faglig kunnskap og rollespill som metode vil kunne gi studentene optimale betingelser for læring via studentaktive arbeidsmåter.

Innledningsvis nevnte jeg hvordan denne typen kunnskap kan være viktig element $\mathrm{i}$ en danningsprosess. Det å være i stand til å utforske læringsmåter og læringsmål kritisk, med basis i egne opplevelser og erfaringer, er kanskje en av de viktigste kunnskaper en lærer kan inneha i en fremtidig skole. 


\section{Et blikk på min egen rolle som en forskende lærerutdanner}

Jeg ser at det å bruke rollespill har vært interessant og morsomt, men også innimellom utfordrende, både faglig og personlig. Før rollespillet om samliv og seksualitet har jeg for eksempel skrevet i loggen min: «I forkant av gjennomføringen er jeg ganske usikker på om dette var et lurt valg. Jeg er ikke spesielt flink å snakke om slike ting».

Å sette i gang slike læringsprosesser kan gi en som lærer følelsen av å miste kontroll over hva som skjer i klasserommet. Det er enklere å gjemme seg bak powerpointer eller lærebøker enn å kaste seg utpå dypt vann med rollespill, i alle fall hvis det er et rollespill med litt løse strukturer. Rollespill kan være uforutsigbart, for eksempel når det gjelder tidsbruk og graden av kontroll. Studenter kommer og går til timene, andre forpliktelser studentene har kan virke konkurrerende, eller studentene er demotiverte av andre grunner. Noen kan ha et negativt forhold til rollespill og har dårlig erfaring med det fra tidligere skolegang. Som lærer vil jeg alltid være usikker på hva som kom ut av rollespillet; lærte de noe nå, eller ble det mest tull? Klarte jeg å stimulere dem til å reflektere over egne referanserammer? Som lærer for studentene må også jeg inneha et analytisk perspektiv på egen rolle; hva slags kunnskap formidler jeg, og er jeg kritisk og reflektert nok i forhold til denne arbeidsmetoden? Er jeg den «kvinnelige samfunnsfagslæreren som er overivrig etter å spille rollespill», som studentene beskrev, og hva betyr dette for mitt eget analytiske ståsted? Å forske på sin egen praksis, i eget felt, lar seg i liten grad forene med å ha en objektiv og distansert rolle som forsker, og dette er ikke alltid forenelig med hva som anerkjennes som forskning. Men: man må få lov til å være både interessert og entusiastisk i forhold til hvordan man organiserer studentenes læringsrom. Å ha disse emosjonelle drivkreftene i eget arbeid er nettopp det som skaper mening for meg i det å være lærer.

\section{Biografi}

Tove Leming er dosent og underviser i samfunnsfag på lærerutdanningen ved UiT, Norges arktiske universitet. Hun er opptatt av studentaktive arbeidsmåter og av studentenes faglige og personlige utvikling i utdanningen. Hun er leder av forskningsgruppen LIFT, som har sitt hovedfokus på lærerutdanning og koblingen mellom lærerutdanning og praksisfelt.

\section{Referanser}

Arre, T., Børhaug, K. \& Christophersen, J. (2014). Introduksjon til samfunnskunnskap. Fagstoff og didaktikk. Oslo: Det Norske Samlaget.

Eik, L. T. (1999). Storyline: Tverrfaglig tilncerming til aktiv laring. Oslo: Tano Aschehoug.

Boal, A. (1985). Theater of the Oppressed. London: Routledge.

Ekebergh, M., Lepp, M. \& Dahlberg, K. (2004). Reflective learning with drama in nursing education- a Swedish attempt to overcome the theory praxis gap. I. Nurse Education Today Volume, 24, (s. 622-628).

Eriksen, A., Larsen, A. B. \& Leming, T. (2014). Acting and reflecting; making connections between theory and practice in teacher education. In Reflective Practice, International and Multidisciplinary Perspectives. 2014. DOI: $10.1080 / 14623943.2014 .969697$.

Eriksen, A. \& Leming, T. (2006). Å skape opplevelsens øyeblikk. I Arneberg, P., Myklebost, G. \& Skare, O. (Red), Fra erfaring til kunnskap (s. 101-120). Tromsø, Norgesuniversitetets Skriftserie 2/2006.

Eriksen, A. \& Leming, T. (2007). «Verden føles urettferdig. Feg vet jeg må gjøre noe snart!»- hvordan skape engasjement og emosjonell involvering $i$ lereprosessen? Tromsø: Eureka Digital 5-2007.

Eriksen, T. H. (2010). Små steder - store spørsmål. Oslo: Universitetsforlaget. 


\section{Tove Leming}

Fangen, K. (2010). Deltagende observasjon. Bergen: Fagbokforlaget.

Filstad, C. (2010). Organisasjonslcering - fra kunnskap til kompetanse. Bergen: Fagbokforlaget.

Freire, P. (1970). The pedagogy of the oppressed. New York: Herder and Herder.

Hammersley, M. \& Atkinson, P. (1996). Feltmetodikk: Grunnlaget for feltarbeid og feltforskning. Oslo: Ad Notam Gyldendal.

Illeris, K. (2013). Transformativ lering og identitet. København: Samfundslitteratur.

Illeris, K. (2012). Lering. Oslo: Gyldendal Akademisk.

Jakhelln, R., Leming, T. \& Tiller, T. (Red.) (2009). Emosjoner $i$ forskning og laring. Tromsø: Eureka.

Klausen, A. M. (1992). Kultur. Mønster og kaos. Oslo: Ad Notam Gyldendal.

Koritzinsky, T. (2014). Samfunnskunnskap. En fagdidaktisk innføring. Oslo: Universitetsforlaget.

Lave, J. \& Wenger, E. (1991). Situated Learning. Legitimate Peripheral Participation. New York: Cambridge University Press.

Mezirow, J. and Associates (2000). Learning as transformation. Critical Perspectives on a Theory in Progress. San Francisco: Jossey-Bass.

Mezirow, J. (2006). An overview on transformative learning. I Crowther, J. \& Sutherland, P. (Eds.): Lifelong learning. London and New York: Routledge.

Utdanningsdirektoratet (2013). Kunnskapssløftet. Mål og innhold i skolen. Samfunnsfag. Hentet fra http://www.udir.no/k106/SAF1-03/

Repstad, P. (2009). Mellom ncerhet og distanse. Kvalitative metoder i samfunnsfag. Oslo: Universitetsforlaget.

Schechner, R. (2003). Performance Theory. London: Routledge.

Starrin, B. (2009). Det våres for emosjoner i samfunnsvitenskapen. I Jakhelln, R., Leming T. \& Tiller, T. (Red.) (2009). Emosjoner $i$ forskning og laring. Tromsø: Eureka.

Wenger, E. (1998). Communities of Practice: Learning, meaning and Identity. New York: Cambridge University Press. 